\title{
Determinants of Table Banking Loan Utilization among Micro Agri- Enterprises Owners in Bomet County, Kenya
}

\author{
Kenneth Chepkwony ${ }^{1}$, Hillary K. Bett ${ }^{1}$, Kenneth W. Sibiko ${ }^{2}$ \\ ${ }^{1}$ Department of Agricultural Economics and Agribusiness Management, Egerton University, \\ P.O. Box 536 Egerton, Kenya \\ ${ }^{2}$ Department of Agricultural Economics and Rural Developmet, Masemo University, Private \\ Bag, Maseno
}

\begin{abstract}
Micro Agri-enterprises (MAEs) play a key role in economic development of Kenya. However, without finance they need to invest, their performance is stifled. Table banking (TB) strategy is an avenue through which MAE owners pool finances together, access credit and business development services. The study objective was to determine factors influencing utilization of table banking loans among MAE owners participating in table banking in Bomet County. Multistage sampling technique was used to select a sample of 382 MAE owners who borrowed longterm loans between 2015 and 2016 from TB groups promoted by Joyful women organization (JoyWO). Semi-structured questionnaires were used to collect primary data. Utilization of TB loans was measured by the amount of TB loan invested in MAE to the total amount of loan borrowed from TB within the study period. Two-limit Tobit model was used to analyse data. Entrepreneurship training received from TB program officers was found to have a positive and significant influence on utilization of TB loans. Location of agri-enterprise, agri-enterprise age and size were other factors found to influence utilization of TB loans positively and significantly. However, gender of MAE owners was found to have a negative and significant influence on utilization of TB loans. To boost utilization of table banking loans among MAE owners, table banking programme officers should tailor entrepreneurship and agribusiness trainings to meet the specific needs required by MAEs owners operating at different stages in the agricultural value chain.
\end{abstract}

Key Words: Table banking, Joyful women organization, Loan, Micro, Agri-enterprise

DOI: 10.7176/ijcab.v3iII.12, urn:nbn:de:0000ijcab.v3iII.127

\section{Cite this Article:}

Chepkwony, K., Bett, H., \& Sibiko, K. (2019). Determinants of Table Banking Loan Utilization among Micro Agri-Enterprises Owners in Bomet County, Kenya. International Journal of Current Aspects, 3(II), 145-158. http://journals.ijcab.org/ journals/index.php/ijcab/article/view/12

\section{INTRODUCTION}

Agribusinesses play a critical role in jump-starting economic transformation through development of agro-based industries that bring much-needed jobs and incomes. They are the catalyst for economic growth and poverty reduction in Africa (World Bank, 2013; Bidzakin et al., 2015). According to Burrows (2015), agricultural Small and Medium Enterprises (SMEs) are important players in the development of agricultural economy. They play a vital role in connecting smallholders with the larger market that buy their produce and that supply them with 
equipment and resources they need to meet market need. Kitaka and Kalio (2015) affirmed that agribusinesses are among the main sources of employment in a majority of the world's poor and developing countries thus the vehicles through which low income people can escape poverty. However, World Bank (2013) report revealed that it is more difficult and costly for entrepreneurs in the agricultural sector and more so for agricultural SMEs to access financial services in Kenya. The report indicated that the average lending rate for private sector loans in 2011 was about 14\%; while, loans to the agricultural sector attracted higher interest rates of between 20$25 \%$. Further, Central Bank of Kenya (CBK) annual report of 2015, indicated that agricultural sector received about $4.4 \%$ of total commercial credit despite being the only sector that recorded a decline in non-performing loans by $23.4 \%$, in the same year (CBK, 2016). Additionally, in the 2016/2017 government budget, agricultural sector was allocated one per cent of total government expenditure despite its contribution of about $26 \%$ to Gross Domestic Product (GDP) of Kenya. The allocation included less than one per cent allocation for transformation of agriculture from subsistence to productive commercial farming (GoK, 2016).

Apart from the high cost of accessing financial services, 2016 financial access household survey report showed that $21.7 \%$ of those who rely on agriculture for their livelihood were financially excluded. It further indicated that reliance on informal financial providers was high but was increasingly being combined with formal service providers. According to the report, the most widely used financial service in Kenya are services from Mobile phone Financial Service providers as it was used by $71.4 \%$ of the population followed by groups such as Rotating Savings and Credit Association (ROSCAs) and Accumulating Savings and Credit Associations (ASCAs) at 41.4\% (CBK, 2016). Kitaka and Kalio (2015), affirmed that the demand-side and supply-side credit constraints have resulted in a yawning financial gap within the formal credit market in Kenya. Consequently, many agribusiness entrepreneurs usually resort to informal sources of credit to finance their businesses. Gichuki et al. (2014) findings indicated that ASCA is one of the effective strategies that can enable more women enterprenuers in the rural and urban centers to access affordable credit. Table banking (TB) strategy is a form of managed ASCA, where members of a particular group meet once every month, place their savings, loan repayments and other contributions on the table then borrow immediately either as long or short term loans. During the meetings, every member makes the agreed contribution and members who have loans make their payment plus the interest. All cash collected is intended to be loaned out in the same meeting, all the transactions are recorded and every member is required to obtain a loan. Loans do not require collateral and there is a high degree of acccountabilty and trust since all the money transactions are perfomed on the table in the presence of all members. Interest rate varies from group to group but ranges between $10 \%$ and $20 \%$ per loan period (Kibaara, 2006; Joyful Women Organization (JoyWO), 2016a). Table banking strategy has better structure than in many arrangements popularly called 'merry-go-round' where people have no repayment schedule. With TB, the groups have to set rules for lending and repayment (Gitobu et al., 2017; Ngumbau et al., 2017 )

In Kenya, the strategy is promoted by Joyful Women Organiztion (JoyWO), a non-governmental organization (NGO) which was registered in 2009 with ultimate objective of empowering Kenyan women economically and to enhance food security (JoyWO, 2016a). Musau (2015) noted that JoyWO require members to form smaller groups of about 15 to 30 members in order to make it manageable at the village level. The contribution is based on the ability of each member and the group`s constitution. However, each group has a minimum and maximum 
amount each member can contribute, to ensure that all the women are on the same economic level. Each member is given a passbook to record transactions. From the money placed on the table, a member can borrow upto twice her contribution for short-term loans, to be repaid within three months. A long term loan, which can be upto three times a member`s shares has a repaiyment period of 6 to 36 months. Loans are processed at the smaller-group level it takes a month to process a long term loan, while short-term loans are given on the spot. Further, JoyWO gives interest-free loans to smaller groups, and the collateral is mostly in form of guarantors. The small groups in turn who re-lend the money, charge their members $10 \%$ interest for short-term loans and $12 \%$ for long-term loans. The interest forms part of the revolving fund and is paid back to members as dividends at the end of the year. The small TB groups can also access credit from Uwezo, and women enterprise funds upon meeting prerequisites set by the government GoK (2015a). As at mid-February 2015, JoyWO had a membership of 182,542 in 12,343 groups with revolving fund of USD 15,856,987.67. The membership was then spread in over 43 counties in Kenya. In Bomet County, for instance, the organization had a total of 8,501 registered members with a revolving fund of USD 495, 001.90 (JoyWO, 2016b). Table banking members are also engaged in capacity building activities to empower them on issues related to group dynamics and entrepreneurship skills. Additionally, they are supported in marketing of their agricultural produce (Musau 2015; JoyWO, 2016c).

\section{STATEMENT OF THE PROBLEM}

Agricultural sector is the backbone of the economy of Kenya. The sector contributes about 26 per cent of Gross Domestic Product (GDP), accounts for 65 per cent of all exports and provides about 18 per cent and 70 per cent of formal and informal employment, respectively (World Bank, 2013). It is for these reasons that the government of Kenya recognizes agriculture as one of the main sectors that will drive the economy towards the achievement of the economic pillar of Kenya Vision 2030. However, lack of access to affordable loans has had a negative impact on agri-enterprises development and performance. Many micro-financial institutions including savings and credit co-operative organizations (SACCOs) and self-help groups are thus now using micro-finance strategies to offer affordable financial services to micro agri-enterprises. However, since the implementation of table banking strategy Bomet County, little is known about factors determining loan utilization among MAEs owners.

\section{LITERATURE REVIEW}

\subsection{Group based micro-finance lending models}

\subsubsection{Merry-Go-Rounds (MGRs)}

Merry-go-rounds are informal groups of people who come together usually for purposes of saving together and borrowing from one another in a rotational manner. In Kenya, MGRs are usually referred to as 'Chama', which is a Kiswahili word for association. Each group is composed of less than 20 members who contribute a specified amount of money regularly. These groups are most common among women mainly for the purpose of buying household items. This model does not charge any interest rate (Kibaara, 2006; Sitati, 2012).

\subsubsection{Rotating Savings and Credit Association (ROSCA) model}

A ROSCA is an associations of 5 to 30 members which offers short-term loans to members at interest rates that range between 5 to 20 per cent per period. The members contribute a fixed amount of money on a regular basis and the total collection is given to one member on a 
rotational basis until everyone has received it. The model plays an important role in savings mobilization in many developing economies (Kibaara, 2006).

\subsubsection{Accumulating Savings and Credit Association (ASCAs) model}

Accumulating savings and credit association refers to self-managed community-based groups that provide their members access to basic financial services. Each association comprises of 15 to 25 self-selected individuals who meet regularly, weekly or fortnightly, to save and, if desired, borrow for short periods, paying monthly interest at a rate set by the group. After approximately 12 months, all savings and earnings are distributed back to group members. They are similar to ROSCAs in that they are also time limited informal microfinance groups. The main differences, however, are that savings can be either fixed or variable and that credit need not be accessed by every member, but by only those that need the loans as per need and opportunity. Interest is charged on loans and this goes into the group's fund which is eventually paid out in bonuses or dividends to members when the cycle comes to an end (Lee, 2010). There are variations in types of ASCAs hence managed ASCAs and Village Savings and Loan Associations (VSLAs). A managed ASCA has a designated facilitator separate from the group who helps train the group members in various aspects of managing the group and its activities and is there to oversee this and manage the group operations. On the other hand, a VSLA model is a group of people who save together and take small loans from those savings. The activities of the group run in cycles of one year, after which the accumulated savings and the interest on loans are distributed back to members. Running VSLAs requires more skills on financial management because of records keeping and management of loans (Sitati, 2012; Gichuki et al., 2014; Hendicks and Chidiac, 2016).

\subsubsection{Financial Service Associations (FSA) model}

Financial service associations, also refered to as "village banks", are community managed credit and saving associations established to provide access to financial services, build community selfhelp groups and help members accumulate savings. They are mainly promoted by Sidian bank (formaly known as K-rep bank). The ownership is not formally registered and membership is acquired through purchase of at least one share at a cost ranging from KES 300 to KES 400. The members contributes towards the share capital and setting up of a physical finacial transaction structure that acts as a 'banking hall'. They offer various financial services including; compulsory savings, voluntary savings, fixed deposit, money transfer, business loans, agricultural loans, education loans, emergency loans and safe deposit. These services are also open to the non-shareholders, however, at a higher fee. Members interested in borrowing loans are required to be members of a primary group. Group members are required to scrutinize the borrower and guarantee to repay the loan in case of default. Each borrower is loaned three times the amount of his/her accumulated shares. Members can decide on interest rates for internally generated savings deposits and on lending their internal fund and usually attracts high interest rates on loans and savings deposits compared to going rates in the commercial banking sector (Holt, 1994; Kibaara, 2006; Langat et al., 2011).

\subsubsection{Grameen Bank (GB) model}

Grameen bank is a rural bank in Bangladesh established in 1983 by Muhammad Yunus. It operates exclusively for the poor on premise that rural people who own too little land to support 
themselves as farmers can nevertheless make productive use of small loans and repay them on time. It also provides organizational support to help the poor make productive use of their credit and income. In delivering credit, GB gives priority to women who are considered the most vulnerable group amongst the poor. The bank replaced physical collateral requirements with group responsibility by organizing poor individuals into groups. Membership in every group is strictly limited to people who; do not own more than half an acre of land, are not members of the same household, have similar economic resources, enjoy mutual trust and confidence, and live in the same village. Each group is assisted by a GB employee. Every member is required to attend all group meetings. The chairpersons conduct group meetings and enforce members' attendance, weekly payments, and discipline. Group chiefs and group chairpersons jointly monitor loan utilization on a daily basis (World Bank, 1995; Sarker, 2001; Bernasek, 2003).

Mobilization of member savings is also an integral part of GB lending. Each member is required to save regularly in a number of different accounts, such as group and emergency funds. Requiring borrowers to save promotes financial discipline and provides an alternative source of finance. It also acts as a deterrent against group collusion, since part of the savings is forfeited if the group disbands, and insures both the borrowers and the lenders against disaster. Each member is required to save at least USD 0.012 every week, which is deposited at the weekly meeting. These contributions are held as individual savings that are refundable when members drop out or retire. In addition, each borrower is required to contribute five per cent of their borrowed amount to the group fund, a payment which is commonly known as group tax one. Unlike their individual savings, group members cannot reclaim this group fund contribution but they can borrow from this fund with the approval of fellow group members at an interest rate determined by the groups themselves. Common lending and collection procedures apply to these loans, including a five percent tax of the principal amount borrowed from the group fund. This is known as group tax two. The group fund is self-managed and can be used for mutually agreed upon purposes (World Bank, 1995). According to World Bank (1995) and Sarker (2001), loan sizes are modest, ranging from USD 75 to USD 250. The group chairperson and bank worker monitor borrowers to see whether they are utilising the money properly. The loan has to be repaid in 50 weekly instalments. Borrowers are not eligible for more loans if they have not paid off their current one. When leaving, borrowers can withdraw the total savings but not the compulsory contribution (that is, group tax one) of five per cent of the loan amount.

\section{MATERIALS AND METHODS}

The study was carried out in Bomet County, Kenya, which covers an area of $2037.4 \mathrm{Km}^{2}$ and is sub-divided into five Sub-Counties namely; Bomet Central, Bomet East, Chepalungu, Sotik and Konoin. Its population was estimated at 723,813 in 2009 population and housing census (GoK, 2011). The County was purposively chosen because agriculture is the mainstay of the County and women groups participate actively in TB (County Government of Bomet (CGoB), 2013). Additionally, it experiences high poverty and financial exclusion rates of $46.5 \%$ and $17.4 \%$, respectively (GoK, 2011). Map of the study area is presented in Figure 1. 


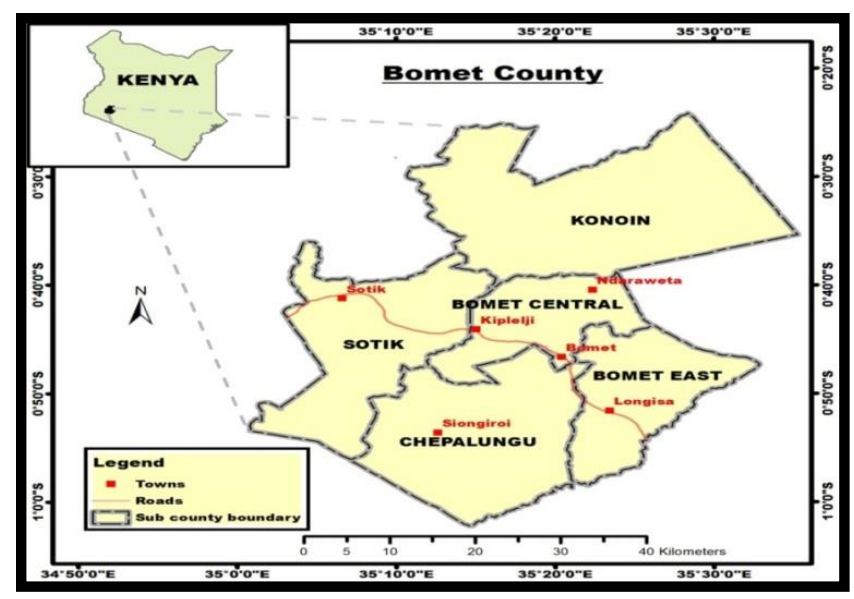

Figure 1: Map of Bomet County showing study area

Source: Kenya Independent Electoral and Boundaries Commission (2012)

The study used multi-stage sampling technique which involved purposive and systematic random sampling methods. In the first stage, Bomet County was purposively due to the aforementioned reasons. In the second stage, the County was stratified based on region into the five sub-counties. In the third stage, purposive sampling was used to prepare a list of those who borrowed long term loans, between 2015 and 2016, from TB groups promoted by JoyWO and were saving in agribusiness booster kitty. Source list was obtained from JoyWO Bomet County manager. Finally, systematic random sampling was used to select the samples from the lists.

The target population of the study was 8,501 TB members in Bomet County. Yamane (1967) formula of sample size determination was used to determine the appropriate sample size. The formula provides that:

$$
n=\frac{N}{1+N(e)^{2}} \text {. }
$$

Where;

$n=$ desired sample size, $N=$ target population size, $1=$ constant, and $e=$ desired level of precision. The size of the population $(N)=8501$ MAEs owners, and $e=0.05$. Therefore,

$$
n=\frac{8501}{1+8501(.05)^{2}} \approx 382 \text { MAE owners }
$$

Out of the 8,501 members registered with various TB groups promoted by JoyWO in Bomet County, the list showed that 2,368 were from Bomet Central sub-county, 2,134 were from Chepalungu sub-county, 1,568 were from Sotik sub-county, 1,381 were from Konoin subcounty, and the remaining 1,050 were from Bomet East sub-county. The required sample per sub-county was determined by proportionate to size sampling method (Kothari, 2004).

$$
n_{i}=\frac{n}{N} \times P_{\text {total }}
$$

Where; 
$n_{i}=$ Desired sample size per sub-county, $n=$ Desired sample size for the study, $N=$ Total number of the target population in the County, and $P_{\text {total }}=$ population per sub-county. The results are presented in Table 1.

Table 1: Proportionate clustering

\begin{tabular}{|l|c|}
\hline Sub-county & Proportionate to size sample \\
\hline Bomet Central & $\frac{382}{8501} \times 2368 \approx 106$ \\
\hline Chepalungu & $\frac{382}{8501} \times 2134 \approx 96$ \\
\hline Sotik & $\frac{382}{8501} \times 1568 \approx 71$ \\
\hline Konoin & $\frac{382}{8501} \times 1381 \approx 62$ \\
\hline Bomet East & $\frac{382}{8501} \times 1050 \approx 47$ \\
\hline Total sample & 382 \\
\hline
\end{tabular}

After permission to collect data from TB group participants was granted by JoyWO through regional human resource manager and Bomet County manager, primary data was collected in February 2017 using pre-tested semi-structured questionnaires. Only those who were able to provide sufficient and verifiable Agri-enterprise records wherein some of the data was captured were considered. Respondents of the study were the MAE owners. Program officers in charge TB groups facilitated access to selected members. To determine factors influencing utilization of TB loans among MAE owners, two-limit Tobit regression model was used. Loan utilization was the ratio of total TB loan invested in MAEs to total loan borrowed from TB. Two-limit Tobit model was the most appropriate econometric model since the ratio had lower limit (zero) and upper limit (one). Entrepreneurs', agri-enterprises characteristics and non-financial services of TB were regressed in the model. The econometric model estimated was;

LoanUtilz $_{i}=\beta_{0}+\beta_{1}$ RdKpg $_{1 i}+\beta_{2}$ MktAst $_{2 i}+\beta_{3}$ EntGndr $_{3 i}+\beta_{4}$ EntAge $_{4 i}+\beta_{5}$ EntMs $_{5 i}+$ $\beta_{6}$ EntHhS $_{6 i}+\beta_{7}$ EntrEducL $_{7 i}+\beta_{8}$ AgrtLoctn $_{8 i}+\beta_{9}$ AgrEntAge $_{9 i}+\beta_{10}$ AgrSize $_{10 i}+$ $\beta_{11}$ ValuAdd $_{11 i}+\varepsilon_{i}$.

Where;

LoanUtilz $_{i}=$ loan utilization, $R d K p g=$ trained on records keeping, MktAst= accessed marketing assistance, EntGndr= entrepreneur`s gender, EntAge= entrepreneur`s age, EntMS=entrepreneur`s marital status, EntHhS=entrepreneur`s household size, EntrEducL= entrepreneur's education level, AgrtLoctn = agri-enterprise location, AgrEntAge= agrienterprise age, AgrSize = agri-enterprise size, ValuAdd=value addition, $\beta_{0}=$ intercept coefficient, $\beta_{1 i} \ldots \ldots \beta_{11 i}$ are the slope coefficients of the respective corresponding variables for observation $i$, and $\varepsilon_{i}=$ Error term. The variables used in the model and their explanation are shown in Table 2. 
International Journal of Current Aspects, Volume 3, Issue II, 2019, PP 145-158, ISSN 2616-6976

IJCAB

Table 2: Variables in two-limit Tobit regression model

\begin{tabular}{|c|c|c|}
\hline Variable & Description & Measurement of variables \\
\hline \multicolumn{3}{|l|}{ Dependent variable } \\
\hline Loan utilization & $\begin{array}{l}\text { Ratio of total TB } \\
\text { loan invested in } \\
\text { MAEs to total } \\
\text { loan borrowed } \\
\text { from TB }\end{array}$ & Values between 0 and 1 \\
\hline \multicolumn{3}{|l|}{ Independent variables } \\
\hline \multicolumn{3}{|l|}{ Table banking } \\
\hline $\begin{array}{l}\text { Entrepreneurship } \\
\text { (Records keeping) }\end{array}$ & Dummy & $1=$ Trained on records keeping, 0 otherwise \\
\hline Marketing assistance & Dummy & $\begin{array}{l}1=\text { Accessed marketing assistance, } 0 \\
\text { otherwise }\end{array}$ \\
\hline \multicolumn{3}{|l|}{ Entrepreneur characteristics } \\
\hline Gender & Dummy & $1=$ Male, $0=$ Female \\
\hline Age & Continuous & Years \\
\hline Marital status & Dummy & $1=$ Married, $0=$ Not married \\
\hline Household size & Continuous & Number of household members \\
\hline Education level & Dummy & $\begin{array}{l}1=\text { Formal education, } 0=\text { No formal } \\
\text { education }\end{array}$ \\
\hline \multicolumn{3}{|l|}{$\begin{array}{l}\text { Agri-enterprise } \\
\text { characteristics }\end{array}$} \\
\hline Location & Dummy & $1=$ Rural, $0=$ Urban \\
\hline Age & Continuous & Years \\
\hline Size & Continuous & Number of employees \\
\hline Value addition & Dummy & $1=$ Yes, $0=\mathrm{No}$ \\
\hline
\end{tabular}

\section{RESULTS AND DISCUSSIONS}

\subsection{Types of MAEs}

Figure 2 shows the main types of agri-enterprises that the respondents were engaged in. Thirty four per cent of the agri-enterprises were poultry farms. The large proportion of respondents engaging in poultry farming was partly attributed to the fact that TB program officers facilitate marketing of poultry products, particularly eggs. The results further showed that majority (76\%) of the respondents were in production farming. This is partly explained by the fact that JoyWO gives loans to support projects such as greenhouse farming, poultry, horticulture, cattle-rearing and overhead irrigation (Musau, 2015). 


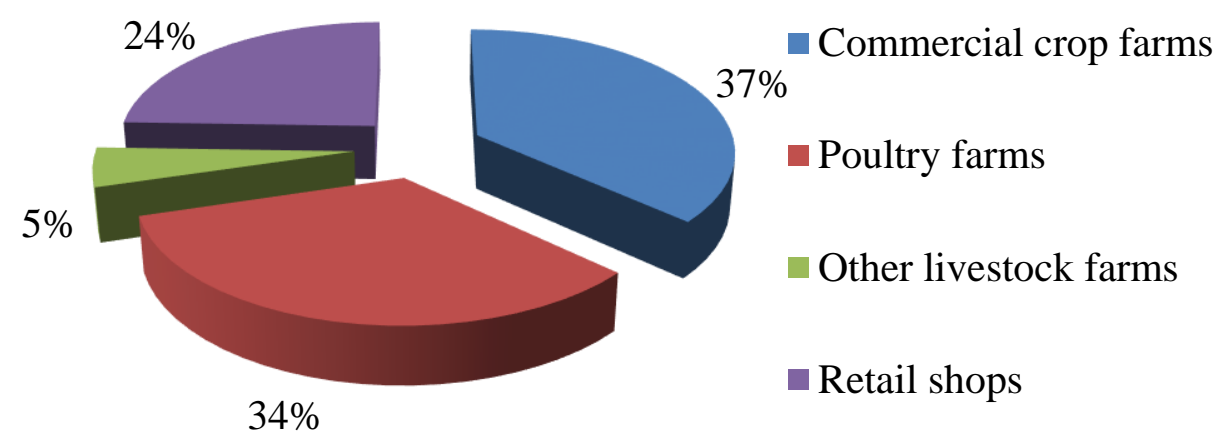

Figure 2: Types of MAEs

\subsection{Sources of start-up capital}

Figure 3 presents the main sources of start-up capital for the respondents. Among the respondents, 17 per cent used proceeds from sale of assets, 16 per cent used savings or loans from self-help groups (other than TB groups) as capital. Dividends and loans from TB was the main source of start-up capital as indicated by 42 per cent of the respondents. According to Musau (2015), JoyWO paid out KES 133,5000,000 (USD 1,500,000) to women as dividends in 2014. Gichuki et al. (2014) also found that substantial amount of annual dividends shared from ASCAs were used by women entrepreneurs to finance capital of their enterprises. In fact, they found that total amount of dividends received from ASCAs influenced changes in gross margins and capital of women owned enterprises. Generally, the results revealed that informal sources of finance were the main source of start-up capital for the respondents.

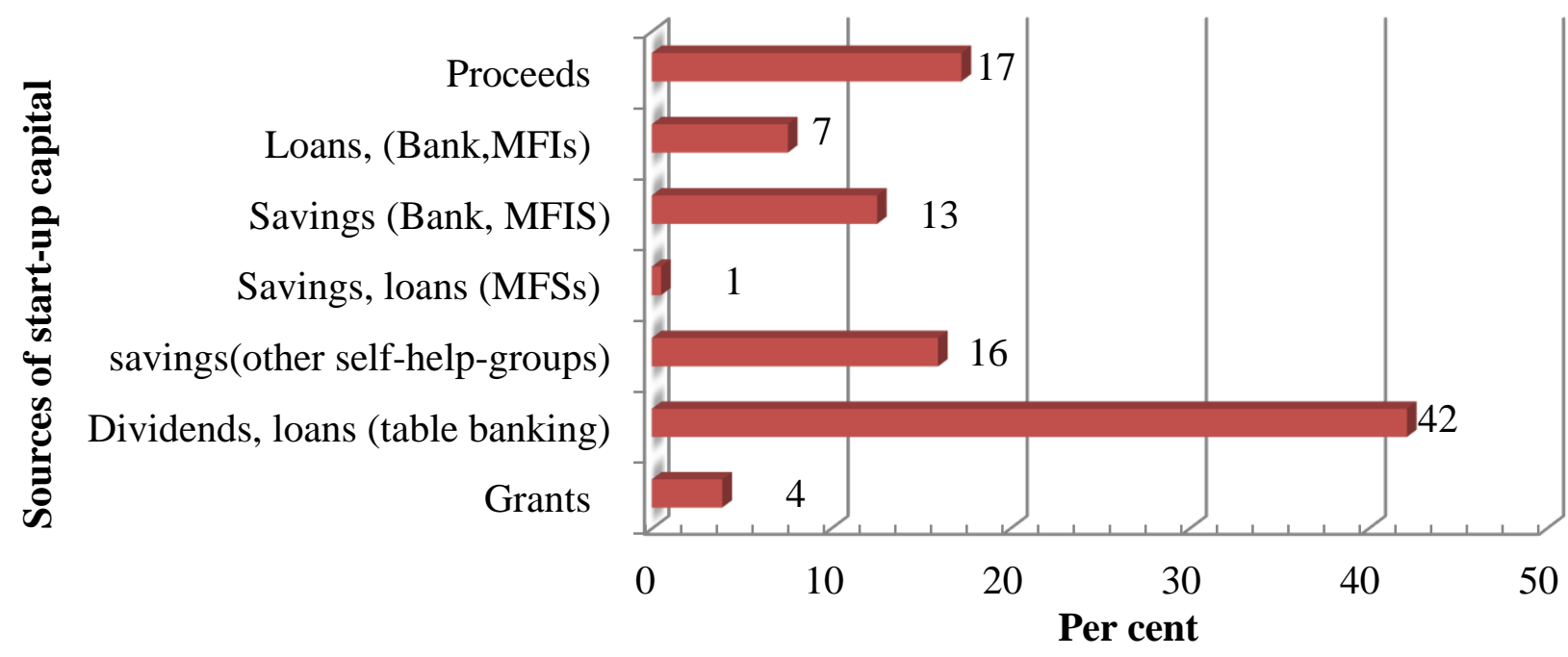

Figure 3: Sources of start-up capital 


\subsection{Loan default}

The respondents were asked whether they, at any point, failed to repay monthly instalments for the long-term loans borrowed from TB. The results are depicted in Figure 4. Six per cent of the respondents indicated that they did default. This proportion is slightly higher than default rate of two per cent indicated by Musau (2015). Neverthless, the low default rate can be partly attributed to the fact that program officers from JoyWO facilitate all TB meetings and ensure that group members are paying back their loans. According to Gebeyehu, Beshire and Haji (2013) loan defaults discourage financial institutions to refinance the defaulting members which put them once again into vicious circle of low productivity.

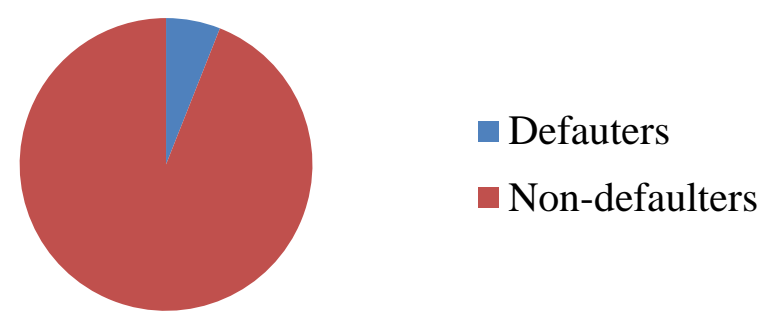

Figure 4: Long-term loan default $(\mathrm{n}=382)$

\subsection{Determinants of TB loan utilization}

Table 3 presents results of the regression model on factors influencing loan utilization among MAE owners. Loan utilization was the ratio of the total loan invested in MAEs to the total loan borrowed from TB groups. Two-limit Tobit model was used to analyse data since the ratio had lower limit (zero) and upper limit (one). The log likelihood for the fitted model of -45.826 and chi-square value of 40.02 indicated that the variables included in the model best specify the functional relationship in the model. The pseudo R-squared of 30 per cent was above the statistical threshold of 20 per cent confirming that utilization of TB loan was attributed to the variables included in the model.

Table 3: Determinants of TB loan utilization

\begin{tabular}{lll}
\hline Loan utilization & Coef. & Std. Err. \\
\hline Records keeping training (1=Yes, 0=No) & $0.007 *$ & 0.025 \\
Marketing assistance (1=Yes, 0=No) & 0.007 & 0.027 \\
Entrepreneur gender (1=Male, 0=Female) & $-0.070^{* *}$ & 0.033 \\
Entrepreneur age (Years) & -0.001 & 0.001 \\
Marital status (1=Married, 0=Not married) & 0.017 & 0.031 \\
Household size (Number of members) & -0.007 & 0.006 \\
Entrepreneur education (1=Formal education,0= No formal education) & 0.078 & 0.065 \\
Agri-enterprise location (1=Rural, 0= Urban) & $0.058^{*}$ & 0.032 \\
Agri-enterprise age (Years) & $0.009 *$ & 0.005 \\
Agri-enterprise size (Number of employees) & $0.030^{* * *}$ & 0.007 \\
Value addition (1=Yes, 0=No) & 0.032 & 0.029 \\
Constant & 0.522 & 0.117
\end{tabular}

Number of obs. $=382$ LR chi2 $(12)=40.02$ Prob $>$ chi2 $=0.0001$

Log likelihood $=-45.825707$ Pseudo R2 $=0.3040$ 
Note: $* * *, * *$, and $*$ indicate significant at $1 \%, 5 \%$ and $10 \%$ level, respectively

A detailed discussion of the factors influencing utilization of TB loans follows. Results of the estimated regression model indicate that one variable was significant at one per cent, one variable was statistically significant at five per cent and three variables were statistically significant at 10 per cent. Training on records keeping influence entrepreneur`s loan utilization positively and significantly at 10 per cent level. Training on records keeping was a proxy for entrepreneurship training. This suggests that access to entrepreneurship training increase loan utilization by 0.7 per cent. This is attributed to the fact that entrepreneurship training enhance entrepreneur`s ability to recognize business opportunities and thus mobilize resources for investment. As a result, the entrepreneur will invest larger proportion of loans borrowed from TB in the agri-enterprise. This finding is consistent with the results of Jain and Parveen (2014) who found that training on enterpreneuship skill increases utilization of loans in productive activities.

The results revealed that gender of MAE owners negatively and significantly influence loan utilization. This implies that male entrepreneurs in TB invest a smaller proportion of the loans borrowed from TB on MAEs than their female counterparts by seven per cent, all other factors held constant. Male entrepreneurs are normally the household heads and thus tend to have a relatively high level of dependence among the family members. Consequently, they may spend a larger proportion of TB loans on household basic needs. This result was inconsistent with the findings of Wale, Geta and Haji (2013) who found that women utilize less microfinance than men. Agri-enterprise location was found to have positive influence on loan utilization at 10 per cent significance level. The results showed that operating an agri-enterprise in rural areas increases proportion of loan being invested in MAEs by 5.8 per cent, other factors held constant. This is because cheap factors of production, land and labour, in rural areas makes agri-enterprise a more viable business venture hence investment of a larger proportion of loans borrowed in the agri-enterprises. On the contrary, there could be other more viable business opportunies in urban centres that are not agri-enterprise related. Therefore, rational agri-enterprise owners operating agri-enterprises in urban centers will invest a larger propotion of the loans borrowed from TB in the more viable business opportunities and thus leaving smaller propotion of the loan for investment in the agri-enterprise. This findings concurs with the findings of Wale et al. (2013) and Ibrahim and Zareba (2015) who found that area of residence influence loan utilization significantly.

Further findings indicate that age of MAE has a positive and significant influence on loan utilization at 10 per cent level. This implies that an addition year of business existence increases the proportion of loan being invested by 0.9 per cent, all other factors held constant. This is attributed to the fact that, in older agri-enterprises, the entrepreneur has confirmed that the business is workable and viable. Moreover, older agri-enterprises benefit from early mover advantages, network effects and reputational effects which enable them to earn a higher margin on their turnover. This motivates business owners to invest a larger proportion of loan borrowed in the agri-enterprise in order for it to grow and thus generate more income. Age of the MAE was also an indicator of years of business experience. This implies that one additional year of business experience increases the proportion of loan being invested by one per cent, holding other factors constant. As the business gets older, the owner gains more business experience. This motivates the entrepreneur to invest a larger proportion of loan borrowed in order to exploit the potential of the agri-enterprise. In determining the factors influencing credit utilization by 
farmers, Orebiyi et al. (2012) found a positive and significant influence of farming experience on loan utilization.

Number of agri-enterprise employees was found to influence loan utilization positively and significantly at one per cent level. Number of employees was an indicator of agri-enterprise size. This suggests that an increase in agri-enterprise size increases the proportion of loan being invested in it by three per cent, other factors held constant. This is explained by the fact that an increase in agri-enterprise size requires more investment in terms of human resource and capital. Consequently, a larger proportion of loan will have to be invested on the agri-enterprise in order to not only operate effectively and efficiently but to also enjoy economies of scale. This finding corroborates the findings of Orebiyi et al. (2012) who found expenditure on labour to influence loan utilization positively and significantly.

\section{CONCLUSION}

Utilization of TB loans is influenced by gender of MAE owner, agri-enterprise income, location of agri-enterprise, agri-enterprise age and the number of employees working in the MAE. Male MAE owners influenced loan utilization negatively. Entrepreneurship training received from TB program officers was another factor that was found to influence loan utilization positively and significantly.

\section{RECOMMENDATION}

To boost utilization of TB loans among MAE owners, they need to be trained on entrepreneurship skills and be engaged on mentorship programmes that encourage them to invest their loans on income generating activities and thus harness more capital. To achieve this, promoters of TB should tailor entrepreneurship trainings to meet the specific needs required by the MAEs owners operating at different stages of the agricultural value chain.

\section{REFERENCES}

Bernasek, A. (2003). "Banking on Social Change: Grameen Bank Lending to Women", International Journal of Politics, Culture and Society, 16 (3), pp. 369-385.

Bidzakin, J. K., Fialor, S. and Brempong, D. A. (2015). Performance of Micro and Small Scale Agribusinesses in Northern Region of Ghana: Non-financial Analysis. Asian Journal of Agricultural Extension, Economics and Sociology, 4(1), 11-20.

Burrows, G. (2015). "Farm Africa calls for support for "first mile" agribusinesses", available at: https://www.farmafrica.org/latest/news/post/ 735-farm-africa-calls-for-support-for-afirstmilea-agribusinesses (Accessed 6 March 2016).

Central BanK of Kenya (2016). The 2016 FinAccess Household Survey, Government Printers, Nairobi.

County Government of Bomet (2013). Bomet County Integrated Development Plan, Government Printers, Nairobi.

Franca, C.N. (2013). "The Impact of Micro Credit Institutions on the Development of Small and Medium Enterprises in Anambra State", IOSR Journal of Business and Management (IOSR-JBM), 14(5), pp. 75-81.

Gebeyehu, Z., Beshire, H. and Haji, J. (2013). Determinants of Loan Repayment Performance of Smallholder Farmers: The Case of Kalu District, South Wollo Zone, Amhara National Regional State, Ethiopia. International Journal of Economics, Business and Finance, 1(11), 431-446. 
Gichuki, C.N., Mutuku, M.M. and Kinuthia, L.N. (2014). "Performance of Women owned Enterprises Accessing Credit from Village Credit and Savings Associations in Kenya", Journal of Global Entrepreneurship Research, 4(16), pp. 1-13.

Gitobu, C.M., Gichunge, E. and Mutegi, D. (2017). "Effect of Table Banking on Growth of Women Owned Small and Medium Enterprises in Meru County, Kenya", International Journal of Current Aspects in Finance (IJCAF), 4(1), pp. 14-29.

Government of Kenya (2011). Kenya County Facts Sheet, Government Printers, Nairobi.

Government of Kenya (2012). National Agribusiness Strategy, Government printers, Nairobi

Government of Kenya (2015a). Training of Trainers (TOT) for UWEZO Fund Management Committee on Introduction to Table banking, Government printers, Nairobi.

Government of Kenya (2015b). Kenya Demographic and Health Survey 2014, Government printers, Nairobi.

Government of Kenya (2016). The Budget Summary for the Fiscal Year 2016/17 and Supporting Information, Government Printers, Nairobi.

Langat, J. K., Mutai, B. K. and Bett, H. K. (2011). Effect of Credit on Household Welfare: The Case of "Village Bank" Credit in Bomet County, Kenya. Asian Journal of Agricultural Sciences, 3(3), 162-170.

Lee, N. (2010). Savings Groups and Self-Help-Groups- Mastercard Foundation. Retrieved from Savings Groups and Learning Initiative: Akha khan development network: http://www.mastercardfdn.org/pdfs/India_85x11_LR.pdf. Accessed: 8-12-2016.

Hendicks, L. and Chidiac, S. (2016). A Pathway to Financial Inclusion for Africa's Poorest Households. Retrieved from Village Savings and Loans: http://www.globalMicro creditsummit2011.org. Accessed: 12-03-2016.

Holt, A. (1994). Entrepreneurship Development Programme. A social science Journal, 4(6), 510.

Ibrahim, H. A. and Zareba, S. A. (2015). Determinants of Loan Utilization and Repayment Behaviour among Small Farmers in North Kordofan of Sudan. Global Advanced Research Journal of Agricultural Science, 4(9), 533-648.

Jain, K. and Parveen, S. (2014). Utilization of Rural Credit by Tribal Women Self-Help-Group Members. International Journal of Agricultural Extension, 5(3), 127-132.

Joyful Women Organization (JoyWO) (2016a). "Table Banking", available at: http://joywo.org (accessed 12 April 2016).

Joyful Women Organization (JoyWO) (2016b). "Table banking Statistics in Every County", availale at: http://joywo.org/our-presence/ (Accessed 12 April 2016).

Joyful Women Organization (JoyWO) (2016c). "JoyWO Kenya", available at: http://joywo.org/ about-us/ (Accessed 12 April 2016).

Kibaara, B. (2006). "Rural Financial Services in Kenya: What is Working and Why?", Agricutural inputs and Services: Impacts on Agricultural Productivity, Competitiveness and Food Security, pp. 89-127. Nairobi, Kenya: Egerton University,Tegemeo Institute of Agricultural policy and Development,

Kitaka, A.N. and Kalio, A. (2015). "Assessing Influence of Structured Loans on Agribusiness Borrowing at First Community Bank, Kenya", International Journal of Economics, Commerce and Management, 3(6), pp. 574-586.

Kothari, C. R. (2004). Research Methodology, Methods and Techniques (2 ${ }^{\text {nd }}$ ed.). New Delhi: New Age International Publishers. 
Musau, Z. (2015). "Loans to women=smart economics/Africa Renewal", available at :http://www.un.org/africarenewal/magazine/august-2015/loans-womensmartecono (Accessed 8 June 2017).

Ngumbau, J.M., Kirimi, D. and Senaji, T.A. (2017). "Reationship Between Table Banking and Growth of Women Owned Micro and Small Enterpises in Uhuru Market,Nairobi County", International Academic Journal of Human Resource and Business Administration, 2 (3), pp. 580-598.

Orebiyi, J. S., Eze, C. C., Henri-Ukoha, A., Akubude, F. C., Ben-Chindo, F. C. and Ibitoye, S. J. (2012). Utilization and Determinants of Institutional Credit of the NACRDB by small Scale Farmers in Imo State, Nigeria. Agricultural journal, 7(5), 360-364.

Osifo, A. A. and Daramola, A. G. (2016). Analysis of Credit Utilization and the Determinants of Micro-Credit in Arable Crop Farming In Edo State, Nigeria. IOSR Journal of Agriculture and Veterinary Science (IOSR-JAVS), 9(7), 54-58.

Sarker, A. E. (2001). The Secrets of Success: the Grameen Bank Experience in Bangladesh. Labour and Management in Developement Journal, 2(1), 1-17.

Sitati, M. (2012). Merry-Go-Round: A Study of Informal Self Help Groups in Kenya. Retrieved from merry-go-round self help groups: https://www.scribd. com/ doc/ 103034444/MerryGo-Round-A-Study-of-Informal-Self-Help-Groups-in-Kenya. Accessed: 04-03-2016. Wale, E., Geta, E. and Haji, J. (2013). Determinants of Microfinance Service Utilization: The Case of Dire Dawa, Ethiopia. Global Scholars Journal of Economics, 1(1), 1-12.

World Bank. (1995). Grameen Bank: Performance and sustainability. Washington DC, World Bank.

World Bank (2013). "Agriculture and Environmental services: Agribusiness indicators, Kenya", World Bank, Woshington, D. C.

Yamane, T. (1967). Statistics: An Introductory (2 ${ }^{\text {nd }}$ ed.), Harper and Row, New York.

This is an open-access article published and distributed under the terms and conditions of the $(c)$ Er Creative Commons Attribution 4.0 International License of United States unless otherwise stated. Access, citation and distribution of this article is allowed with full recognition of the authors and the source.

Authors seeking to publish with an International Peer Reviewed Journal should consider www.ijcab.org by writing to the Editor at editor@ijcab.org. List of our Journals are Available at www.ijcab.org/journals 